\title{
Metaphoric Perceptions of Teachers and Administrators towards Uplifting Leadership
}

OPEN ACCESS

Manuscript ID:

EDU-2021-09033803

Volume: 9

Issue: 3

Month: June

Year: 2021

P-ISSN: 2320-2653

E-ISSN: 2582-1334

Received: 03.03.2021

Accepted: 20.04.2021

Published: 01.06.2021

Citation:

Özçetin, Serdar.

"Metaphoric Perceptions

of Teachers and

Administrators towards

Uplifting Leadership."

Shanlax International

Journal of Education,

vol. 9, no. 3, 2021,

pp. 57-66.

DOI:

https://doi.org/10.34293/

education.v9i3.3803

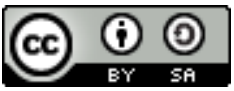

This work is licensed under a Creative Commons Attribution-ShareAlike 4.0 International License

\author{
Serdar Özçetin \\ Assistant Professor, Akdeniz University, Antalya, Turkey \\ https://orcid.org/0000-0003-0797-5268
}

\begin{abstract}
This study aimed to determine the perceptions of teachers and administrators about the concept of uplifting leadership in depth through metaphors. In this study, phenomenology design, one of the qualitative research methods, was used. The study group of the research consists of 30 people, 15 administrators and 15 teachers who work in primary, secondary and high schools affiliated to Antalya Directorate of National Education and selected through snowball sampling, which is purposeful sampling methods. A structured questionary form was used as a data collection tool. Metaphors were used as a data collection method and the participants were asked to explain what they think uplifting leadership resembled with reasons. Descriptive analysis was used to analyze the data. The responses of the participants were classified and analyzed; the analysis was supported by direct quotations from the participants. NVivo package program was used to encode and classify the data. As a result of the study, it has been found that the metaphors produced by the participants contain features of the uplifting leadership by the changing management perception, such as being contemporary, constantly improving itself by following the innovations, trying to save organizations from the static structure, exciting employees for their improvement or institutional improvement, teaching them to dream, supporting different ideas, working in cooperation.
\end{abstract}

Keywords: Leadership, Uplifting leadership, Metaphor, Teacher perception, Administrator perception

\section{Introduction}

Although leadership is a field of study within the scope of social sciences (sociology, psychology, management, politics), a common language has not been formed regarding the meaning of leadership. Many different definitions have been made in the literature regarding this concept (Şişman, 2002). According to Yukl, leadership starts when a cluster member motivates other members or changes their competencies (Başaran, 1992). Stogdill called leadership a function of the interaction between the individual and the group (Şişman, 2002). According to Katz and Kahn, rather than mechanically adapt to monotonous orientations of organization members, it creates an extra effect on their behavior by directing them to perform (Erçetin, 1998).

According to Spillane and Orlina (2005), it is seen that among many definitions of leadership, the research results of three basic theories lack in some aspects to explain the phenomenon of leadership, and this field should be open to innovation with a continuous change. The changing working conditions, especially in line with the requirements of the age, and the differentiation of the needs of both managers and employees over time bring new theories to the agenda in leadership approaches. There may be difficulties from time to time in making a classification while evaluating new approaches. While some sources in the literature evaluate new approaches, in the studies recently carried out on leadership, they have taken the terms "transaction" discussed by Mc Gregor Burns in the late 1970s and "transformation," which was focused on in the 
1990s as two separate points and they combined new approaches in the term "transformational" (Beycioğlu, 2009). One of the leaderships considered in line with new approaches is the concept of uplifting leadership.

\section{Uplifting Leadership}

Uplifting among people and organizations is a force that improves performance and enables unexpected success when higher goals are set. Uplifting on a personal level affects emotions. To uplift is about the effect of uplifting on performance and the ways to achieve it. It's a small word that makes a big impact. This expression has intertwined meanings related to performance at work and life, meaning emotional and spiritual unity (Hargreaves, et al., 2014).

Uplifting actions and words are contagious: Their effects spread around and affect others. When the person is uplifted, they uplift other people around them and the uplifted people maintain that uplifting. In other words, uplifting is a mutual process. When people uplift each other's souls, they attain a higher moral foundation and thus transcend themselves (Harris, 2015).

With effective leadership, the spiritual, emotional and moral uplift within the institution and in the community affected by the institution increases performance (Bass, 1985). There are some sources stating that sustainable high performance comes from focusing on values rather than profit. Improving performance, however, does not come about solely by focusing on the process. It's not just about wishing and hoping; it's more about having emotional intelligence and providing better support to others (Hargreaves, et al., 2014). Uplifting leadership can also eliminate the shortcomings of teammates by providing reliable relationships. Uplifting leaders are in constant development and struggle to achieve better than the current situation by collaborating with their competitors. Uplifting leaders can influence others in the organization by collaborating with team members to exceed expectations (Hargreaves et al., 2014; Harris, 2015; Hargreaves \& Harris, 2011).

Hargreaves, et al., (2014) identified six elements (dreaming with determination, creativity and counter-flow, collaboration with competition, pushing and pulling, measuring with meaning, sustainable success) that led to higher objectives and performance. These processes include determining a clear directive on where to go, how to get there, and raising awareness for this view on the whole team.

Uplifting leaders are influential people who use effective institutional structures based on solid foundations, establish high-grade trustworthy relationships. They are harsh enough to dare to encounter ideas contrary to the idea and cheerful enough to accommodate creativity. Thus, uplifting leadership combines short-term success with longterm sustainability. The beginning of uplifting leadership is the individuals themselves, as in other leaderships. Uplifting leadership isn't just about being positive or confident. Uplifting leadership also carries the characteristics of inspirational and transformational leadership. Besides, they act as elevators that enable others to rise as well by sharing their leadership. (Hargreaves, et al., 2014).

Uplifting leaders are perceived and watched by the groups they contact and transformed into a meaningful structure in people's minds. When the meanings formed in the minds are expressed somehow, they can be noticed by other people. There are various ways of expressing mental perceptions. One of different ways of interpreting and expressing is "metaphors" (Akın-Kösterelioğlu, 2014).

\section{Metaphors}

Metaphors are a dominant component of figurative language, reflecting the cognitive processes in which people perceive the reality they encounter (Witherspoon \& Crawford, 2014). They are mental structures that reflect how people experience and shape their reasoning (Günbay1, 2011).

A metaphor is a perception tool (Arnett, 1999). Lakoff \& Johnson (2005) stated that metaphors are the main linguistic tools discovered by human beings to understand, explain, construct and organize the world. For this reason, they stated that metaphors would help people understand how they construct their reality and how they perceive the world (Saban, et al., 2006; Semerci, 2007). According to Aslan and Bayrakçı (2006), metaphors are a powerful mind mapping and modeling mechanism for individuals to understand and construct their world. Thus, 
metaphors have the power to create meanings beyond those specific to the original semantic fields. In this context, Murray \& Rosamund (2006) defined metaphor as a basic cognition mechanism; that is, the essence of the metaphorical process is the way of thinking about a particular subject in terms different from its original field.

This study, it was aimed to determine the perceptions of teachers and administrators about the concept of uplifting leadership in depth through metaphors. To achieve this aim, the metaphors that teachers and administrators have about the concept of uplifting leadership were evaluated.

\section{Method}

\section{Research Design}

In this study, which aims to determine the perceptions of school administrators and teachers about uplifting leadership in-depth, the phenomenology design, one of the qualitative research methods, was used. Phenomenology design tries to determine the perceptions and reactions of individuals about an event in depth based on their experiences (Moustakas, 1994; Fraenkel, et al., 2011; Yıldırım \& Şimşek, 2011).

\section{Study Group}

The study group of the research consist of 30 people, 15 administrators and 15 teachers, who work in primary, secondary \& high schools affiliated to Antalya Directorate of National Education, \&selected through the "snowball or chain" sampling method, which is one of purposeful sampling methods "effective in identifying individuals or situations that can be a rich source of information about the researcher's problem" (Yıldırım \& Şimşek, 2011).

Six of the school administrators participating in the study are principals and nine of them are vice principals. When the distribution of managers by gender is examined, there are six male principals and four male and five female vice-principals in the study group. The working periods of administration vary between 2 to 18 years; their total working time varies between 8 to 26 years. Out of the 15 teachers participating in the study, there are seven female and eight male participants. Teachers' working periods vary between 8 and 26 years.

\section{Data Collection Tool}

Metaphors were used as a data collection method. For this purpose, a structured questionary form was used to determine the metaphors developed by the study group regarding uplifting leadership. Participants were asked to explain what they think uplift leadership resembles with their reasons.

\section{Collection and Analysis of Data}

Descriptive analysis was used to analyze the data. Descriptive analysis refers to a four-stage process: (1) creating a framework for descriptive analysis, (2) processing data according to the thematic framework, (3) defining the findings, (4) interpreting the findings. (Crabtree \& Miller, 1999; Creswell, 2002; Hay, 2000; Marshall \& Rossman, 2014; Miles \& Huberman, 1994; Seidman, 2006). For this, the data were first transferred to the computer environment. The questions asked to the participants were determined as six main themes, taking into account the prominent phenomena in the conceptual framework on which the research on uplifting leadership is based (Hargreaves, et al., 2014) and analyzes were made by creating codes from the generated metaphors. The responses of the participants were classified and analyzed and, the analysis was supported by direct quotations from the participants. NVivo package program was used to encode and classify the data. For the participants to answer the questions sincerely, their names are not specified but coded and kept confidential by the researcher. While quoting the opinions of the participants, (T) was used for teachers and (A) for administrators in the coding system.

\section{Validity and Reliability of Research}

To ensure the validity of the research, in the preparation of the data collection tool, the prominent facts in the conceptual framework on which the researches (Hargreaves, et al., 2014) on uplifting leadership are based were taken into consideration. To increase external validity (transferability) of the study, detailed description \& purposeful sampling methods were used (Yıldırım \& Şimşek, 2011).

To increase the internal reliability (consistency) of the research, the consistency analysis method was used. The Kohen Kappa consistency coefficient 
was calculated by two independent researchers to determine the reliability of the comparative agreement between the encodings. It was found to be significant at the 0.93 level. It was concluded that the encodings were reliable between the two researchers.

\section{Findings}

The metaphors produced by the participants were classified into six main categories. The metaphors produced under this title and their related categories are given in Table 1:

Table 1: Metaphoric Analysis Results on Uplifting Leadership

\begin{tabular}{|l|l|c|}
\hline \multicolumn{1}{|c|}{ Theme } & \multicolumn{1}{|c|}{ Encodings (Metaphors) } & \multicolumn{1}{c|}{ n } \\
\hline Dreaming & Contagious Disease (1), Magic Wand (1) & 2 \\
\hline $\begin{array}{l}\text { Creativity and } \\
\text { Counterflow }\end{array}$ & $\begin{array}{l}\text { Polygon (1), Crystal Ball (1), Music Box (1), Peacock (1), Chameleon (1), } \\
\text { Shark (1) }\end{array}$ & 6 \\
\hline Cooperation & Bee (2), Snowball (1), Cooking Pot (1), Queen Bee (1) & 5 \\
\hline Push and Pull Force & $\begin{array}{l}\text { Fire (1), Bomb (1), Exotic Perfume (1), Bird (1), Squirrel (1), Seesaw (1), } \\
\text { Peacock (1), Vitamin Pill (2), Rope (1), Eagle (1) }\end{array}$ & 11 \\
\hline Meaningful Measurement & Plane (1), Invisible Man (1), Wrench (1) & 3 \\
\hline Sustainable Success & Stream (1), Contagious Disease (1), Heritage (1) & 3 \\
\hline
\end{tabular}

When Table 1 was examined, two participants compared the uplifting leadership to infectious disease and magic wand in the theme of dreaming. They compare it to a communicable disease because they think that the uplifting leaders make their dreams come true by spreading their energy around them. A6 expresses this situation in his words, "I would compare this to a contagious disease. If you engage very closely with uplifting leaders, you will surely get infected. Its effect on you is as much as your contact with them. If you get too close, it will surely pass. If you have a dream, it will also be passed, which means the dream comes true." The analogy to the magic wand is that the uplifting leaders are the people who can dream and can realize the dreams of their followers. T14 expressed this situation in his words, "I compare this to a magic wand. Because with this wand, you can be happy by fulfilling what you want. For uplifting leaders, if you have a dream about yourself or your organization, if you need someone to make them come true, he's the uplifting leader. If you do not have a dream, they will create a dream for you."

Six of the participants compared the uplifting leadership to the polygon, crystal ball, music box, peacock, chameleon and shark, taken from the themes of creativity and counterflow. Comparing polygon and crystal ball is that they think that refreshing leaders can develop different perspectives and are versatile. T11expresses this situation in his words, "I compare this situation to a polygon.
Because it expresses versatility, one-sidedness brings ordinariness and failure to the individual, but uplifting leaders should be in the form of polygons. You do not look from a single point of view, since the polygon has many corners; I compare it to a polygon because they are the people who do not look from a single point with different perspectives." T7, on the other hand, expresses this in his words "We can compare it to the crystal ball, it can be associated with uplifting leadership in terms of representing a versatile perspective. We can think of a crystal ball in the shape of a sphere, allowing us to look from multiple directions."

The reason they compare it to the music box and the peacock is that they think that the uplifting leaders excite people with an innovative structure when you do not expect it. A7 expresses this situation in his words, "A clown can come out of them like a music box. They created very innovative things when you did not expect it, does new things by going out of the box and cheers up those around you." A10 expresses this situation in his words, "They look like a normal bird, like a peacock, but when it puffs its feathers, it creates a serious impact around them. You can't see anything directly when you look at them, but when you listen to them, when you get a little closer, it's like a peacock that is very creative, surprising and making an impact." The reason they compare uplifting leaders to chameleons that they think that they adapt to the challenges and are innovative by presenting different thoughts. T9 expresses this in 
his words, "I compare them to a chameleon. Because they can change according to the situation, in other words, there can be compelling structures during the education process, and it is necessary to keep up with these situations. This is a feature that the chameleon has. For the people or the environment to stay alive, everyone can be uplifted by changing the shape to meet their needs and expectations." The reason for comparing them to sharks is that they think uplifting leaders are people who constantly improve themselves, set an example for the people around them and contribute to their development. T10 expressed this situation in his words, "Uplifting leadership, I compare it to a shark. Because they have to be in constant motion, when the shark stops, they cannot breathe and dies. Sharks need to eat constantly. Uplifting leaders should be in the same constant motion, the moment they start to wait, they will regress, and those who follow will also regress. That's why there should be ideas that constantly improve themselves, set an example for the people around them, contribute to their development, and create excitement for them."

Five of the participants compared the uplifting leadership to the bee, snowball, cooking pot and queen bee, all of which are included in the collaboration theme. The reason why the participants compare the uplifting leadership to the bee is that they think that the uplifting leaders can work in coordination with the environment and organize them. T3 expressed this situation in his words, "I can compare this to a bee. Because the bee performs the job, they have in the hive as a part of a whole without complaining." A12, on the other hand, expressed that, "I compare it to bees. Because they are constantly active, they even control very distant places. By notifying other members of the rich flowers they find, they can mobilize everyone. When flowers bloom, they invigorate them by pollinating them and enliven the nature." The reason for comparing it to snowballs is that they think the effect of uplifting leaders create is constantly increasing, adding strength to the people around them. T5 expresses this situation in his words, "I can compare to a snowball left from the hill because it gets stronger as it descends from the hill and adds strength around it. Also, its color is white so that it can mean good without evil. I can say that because of its structure that adds strength to its power." The reason for the analogy with the cooking pot, they think that the uplifting leaders can work harmoniously in the same environment with many people with differences. T13 expresses this situation in his words, "I can compare it to a pot. It turns a variety of products into a delicious meal." The reason why the participants compare the uplifting leadership to the queen bee is that they think that the uplifting leaders have an attraction power that attracts people by working in harmony with the environment they live in. A9 expresses this situation in his words, "I can compare it to a queen bee. Because the queen bee can make other bees work in harmony depending on her in the hive. It has a bond with other bees and if the queen bee is not in the hive, other bees will die as well. Uplifting leaders likewise have a power of attraction and work in harmony with the people around them. He coordinates them well and there is a total work."

Eleven participants compared the uplifting leadership to fire, bomb, exotic perfume, bird, squirrel, seesaw, peacock, vitamin pill, rope and eagle, within the theme of push and pull power. The participants compare the uplifting leadership to fire, bombs, squirrels, peacocks and vitamin pills think that the uplifting leaders are people who enlighten their surroundings and spread their energy, leadership effect and power around them. T12 expressed this situation in his words, "I compare this to fire. Because fire illuminates the darkness, this is the purpose of education; to illuminate the darkness in people. When we look at uplifting leaders, they spread their fire to other people, warming other people. When we look at the fire, it tells the excitement within, and we can take this in the sense of sharing it with others." A2 expressed this situation in his words, "I compare it to a bomb. Because when it explodes, it will spread its energy and power around it. It is, in a way, like a butterfly effect, an uplifting effect will spread around it, it will contribute to the development and uplift of the school by spreading to the people around." T4 expresses this in his words, "I think uplifting leaders are like squirrels. Because they are active, he cannot stand. Still, their energy is very beautiful; they are sympathetic. I think their energy is also nice. They give this energy to other people." 
Y11 expressed that, "I can compare this to vitamin pills. When the body is weak, we help the body's immune system develop by giving vitamins and obtaining warrior cells. An uplifting leader is also a leader who, like the vitamin of his institution, produces solutions to the problems of the institution and gives hope and excitement to his environment while producing a solution" A3 expressed this situation in his words, "It is like vitamin pills that will activate people when you take the vitamin pill, you start to act after a certain period, you become dynamic, you want to do something, you want to run; uplifting leadership is something like this and activates people; uplifting leader shares love and excitement inside them with others, excites them and creates a desire to do something." The reason why the participants compare uplifting leadership to exotic perfumes, birds, seesaws, ropes and eagles is that they think uplifting leaders are the people who contribute to the development of individuals and make them rise. T2 expressed this situation in his word, "I compare to the scent of exotic perfume. Because, even if you walk sluggishly while going on the road, you will look around when you smell it even if you do not see that person. Likewise, uplifting can raise the energy of sleeping or the swaying lethargic teacher, student, and administrators." T1 expressed this situation in his words, "I compare it to a bird. Because I have compared the uplifting leadership to birds because they can fly high, you can go wherever you want; you have freedom, you can go high.

In the same way, I thought that uplifting leaders are people who have communication with everyone, who have a wide range of influence and enable the development of the individual towards the heights." A1 expressed that, "Seesaw came to my mind. The part below can be colleague, teacher, principal; on the higher side, uplifting leaders can push it to rise and revive." A5 expressed this situation in his word, "I compare it to a peacock. Because it is undergoing a change and excites the people around it, it is magnificent.

For this reason, there is a change of the peacock is a self-prepared change that develops gradually since the hatching. As an education unit, you develop yourself in a certain time and you excite the people around you and make an impact on them."
A13 expressed this situation in his words "Uplifting leadership can be a rope, a rope that helps to grab and pull a teacher or a person in the swamp." A8 expressed this situation in his words, "I compare it to an eagle. Because the eagle has a keen gaze, it knows where an event is and what is happening. Uplifting leaders are people who know what is happening to students in their school, what is happening everywhere, help them and contribute to their development."

Three participants compared the uplifting leadership to an airplane, invisible man, and wrench in a meaningful measurement theme. The reason for comparing it to a plane is that they think the uplifting leaders can make accurate evaluations by developing both a close and distant perspective on their students. A14 expressed this situation in his words, "I want to compare this to an airplane. Because the plane takes off from the ground and you see the whole process when it takes off. This is the same in uplifting leadership. If the leader is involved, he is at every stage of the business and can see what has been done from the height. In other words, you can see a city from far away while you are in the air on the plane; you can see it closely during the landing process. The uplifting leader is like that; he sees it from a distance; when necessary, he can get to know his students closely and approach them correctly and make correct evaluations. The reason for comparing to the invisible man is that they think that uplifting leaders make correct evaluations as good followers of their students. T6 expressed this situation in his words, "They can be compared to invisible man because the invisible man can enter the environment, he desires without anyone noticing, and see all the good and bad behaviors of everyone in the environments he wants. Uplifting leaders also identify their students' out-ofschool activities as a good leader to their students and evaluate them not only through written exams but by actually getting to know them." The reason for the comparison to the wrench is that they think that uplifting leaders use different measurement methods by identifying different abilities. A15 expressed this situation in his words, "It is like a wrench. Even though there are different sizes of screws, all screws are loosened or tightened with a wrench because it is adjustable. Uplifting leaders also behave so that their employees or students with different characteristics 
can discover these characteristics and experience a sense of achievement. In other words, a student may be talented in sports and a student in painting; they should be brought to the forefront, not all students should be put in the same mold. By determining these, appropriate measurement methods should be used. The same success should not be expected for everyone in the same exam."

Three of the participants compared the uplifting leadership to the stream, contagious disease, and heritage taken into the theme of sustainable success. Comparing it to the stream is that they think that uplifting leaders give life and shape their environment. T8 expressed this situation in his words, "I compare refreshing leadership to a stream. Because the stream changes the soil it passes through, and the stream flowing in a controlled manner gives life to its environment. We are open to innovation in uplifting leadership; we bring life there, give life to future generations, and train future generations. Uplifting leaders will give life to their students, who are the environment they are in, and they will later form future generations." The reason for comparing to the contagious disease is that they think when the uplifting leaders initiate an effect, that effect is an endless process. A4 expressed this situation in his words, "I compared it to disease because it is something you have to undergo its effect. Because it is a process that does not end before you realize what you aimed. Even if you say it's over, it doesn't end; it goes on continuously." The comparison to heritage is that they think the uplifting leaders make long-term development plans by considering the people they will transfer to next while fulfilling their responsibilities. A15 expressed this situation in his words, "I compare this situation to a heritage. Because once inherited, you can exhaust that legacy or add something on top of it and leave a stronger heritage to future generations. The uplifting leaders make long-term plans by adding to their heritage instead of enjoying their heritage in the short term, making them and those who come after happy."

\section{Conclusion, Discussion and Suggestions}

The aim of this research is to reveal the perceptions of teachers and administrators towards the concept of uplifting leadership through metaphors.
30 metaphors produced by 15 teachers and 15 administrators working in the central schools of Antalya province for the concept of uplifting leadership were analyzed. When the research metaphors are divided into six different conceptual themes, it is seen that the most metaphorized themes are "Push and Pull Power" with 11 metaphors in the first place, "Creativity and Counterflow" with 6 metaphors in the second and "Cooperation" with 5 metaphors in the third. The least metaphor-produced theme is the theme of "Dreaming" with 2 metaphors.

When the metaphors forming the theme of dreaming are examined, the metaphors of infectious disease and magic wand are produced. With these metaphors, it was concluded that the dreams, which are the starting point of uplifting leadership, are spread by the uplifting leaders to the people around them, and these leaders can also realize the dreams of the people around them. This result is similar to the view in Harris's (2015)'s study that "uplifting actions and words are contagious, their effects spread and affect others." Similarly, the result of "It is understood that according to the metaphors in the category of School Principal as a Guiding and Leader, school principals guide all the staff, students and parents of the school, especially the teachers" in the study of Korkmaz \& Çevik (2018) shares similarity to guiding them to the realization of dreams. Again, the result of "school principals are seen as a source and tool of development with their advisory roles and inspiring features" in the study of Şahin \& Sabanc1 (2018) is similar to the result of the study which is creating dream by inspiring and realization of these dreams.

Polygon, crystal ball, music box, peacock, chameleon and shark metaphors were created in the theme of creativity and counterflow. With the produced metaphors, it has been concluded that uplifting leaders can develop different perspectives, are versatile, have an innovative structure, have a structure that excites people, constantly improve themselves, set an example for the people around them and contributes to their development. This result stated in the study of Gök (2020) that "qualified people can affect both their institutions and their environment." It has also been stated that having merit and being open to development progress in 
parallel" can be supported by the findings. Similarly, in the study of Akbaşlı \& Diş (2019), it is mentioned that leaders should have a personality feature such as being open to innovations. In the study by Memişoğlu \& Y1lmaz (2019), the metaphors made in innovation / creativity about the important roles of leadership such as "revealing the potential, providing innovation and change" show similarities with the results of this study. Some information in the literature supports these results. Leaders should be creative and innovative (Barutçugil, 2006). Leaders who are creative and innovative creative and support change. It is very important for the leader to attach importance to change and creativity to adapt to the changes and innovations brought by the 21 st century and to realize the innovations and changes required by the age in his school (Sabuncuoğlu, 2008) because leaders can transform their organizations as change agents (Hoy \& Miskel, 2012).

The metaphors of bee, snowball, cooking pot and queen bee, which was taken into the theme of cooperation, were produced. With these metaphors created by the participants for uplifting leadership, it has been reached that the effect created by uplifting leaders is constantly increasing by empowering the people around them and that they can work in harmony with many people who have differences, uplifting leaders can work in coordination with the environment and organize them, and have a power of attraction. Leadership research and practices show that it is better to have a more collaborative / negotiant structure regarding the leader's role (Van Kupperberg \& Sitkin, 2013; Schechter, 2011). In Aydoğdu's (2008) study, the metaphors most frequently produced by teachers regarding the ideal school administrator are "parent," "scales," "queen bee," and "a precious stone" metaphors, respectively. It can be said that it is similar to the queen bee metaphor in these studies. It shows similarities to the meaning of the metaphors produced in the studies of Dönmez (2008), Yalçın (2011), Yalçın \& Erginer (2012), Korkmaz \& Çevik (2018). According to these studies, it is understood that teachers see the principal as someone who provides the connection and liaison between all stakeholders related to the school, such as teachers, students and parents.
The metaphors of fire, bombs, exotic perfumes, birds, squirrels, seesaws, peacocks, vitamin pills, rope and eagle, were created within the theme of push and pull power. With these metaphors produced by the participants, it was concluded that uplifting leaders enliven the stationary people in the organization by attracting them, spread their energy and power around them, and sometimes use the push force that makes people do some things. That teachers explain the leader with the most master and clock metaphors in terms of the ability to do the right things and make others do the right things in the study of Yıldız \& Ertürk (2019) shows similarities with the result of this study that uplifting leaders attract people towards themselves to save them from static state and make them do something.

Under the meaningful measurement theme, the metaphors of the plane, the invisible man, and the wrench were produced. From these metaphors, it was found that the uplifting leaders developed both distant and close perspectives on their students, were good followers of their students, identified their students with different abilities, used different measurement methods and made accurate evaluations. The conclusion in the study conducted by Gök (2020) that managers can become capable by knowing their employees closely with accurate and meaningful evaluation principles, not according to certain characteristics, supports the meaningful measurement theme.

Metaphors of stream, contagious disease and heritage were produced within the theme of sustainable success. It is understood from these metaphors that uplifting leadership should have a continuous structure. It has been concluded that uplifting leaders are the people who give life to their surroundings, and when they initiate an effect, that effect is an endless process. This result shows similarities in terms of sustainability with the result of Korkmaz \& Çevik's (2018) study, “teachers tend to see the school principal as the common point where everyone meets. This function of a school principal is important in terms of ensuring organizational harmony and organizational continuity within the school." The result of the study of Y1ldız \& Ertürk (2019), "School administrators should care about development and change and preserve the existing 
and should support activities and initiatives that will contribute to the development of the school and teachers" supports the result of this research.

In the light of the data obtained as a result of the research, the metaphors that the teachers and administrators participated in the study used to reveal how they perceive uplifting leadership was presented. When the data obtained are evaluated, it has been found that the metaphors produced by the participants have features like being contemporary by the changing management perception of the uplifting leadership, constantly improving itself by following innovations, trying to save organizations from the static structure, exciting employees for their development or institutional development, teaching them to dream, supporting different ideas, enabling them to cooperate.

The support of uplifting leaders is needed to save educational institutions from stagnation. Practitioners can revive the institution by spreading their uplift throughout the school. Researchers may also be suggested to develop studies that will conceptually enrich uplifting leadership and to develop qualitative and quantitative tools that can measure.

\section{References}

Akbaşl1, Sait, and Okan Diş. "Competencies of School Managers as a Leader According to Teachers' Views." International Journal of Leadership Studies: Theory and Practice, vol. 2, no. 2, 2019, pp. 86-102.

Akın-Kösterelioğlu, Meltem. "Metaphoric Perception of Preservice Teachers Towards the Concept of School Administrator." Journal of World of Turks, vol. 6, no. 3, 2014, pp. 115-133.

Arnett, Robert C. "Metaphorical Guidance: Administration as Building and Renovation." Journal of Educational Administration, vol. 37, no. 1, 1999, pp. 80-89.

Arslan, M.M., and M. Bayrakçı. "An Examination of Metaphorical Thinking and Learning from Educational View." Millî Ĕgitim Dergisi, 2006, pp. 100-108.

Aydoğdu, Elif. İlköğretim Okullarındaki Öğrenci ve Ögretmenlerin Sahip Olduklarl Okul Algıları Ile Ideal Okul Algılarının Metaforlar
(Mecazlar) Yoluyla Analizi. Osmangazi Üniversitesi, 2008.

Barutçugil, İsmet. Yöneticinin Yönetimi. Kariyer Yayıncilık, 2006.

Başaran, İbrahim Ethem. Yönetimde İnsan İlişkileri, Kadığlu Matbaası, 1992.

Beycioğlu, Kadir. Ilkögretim Okullarında Ögretmenlerin Sergiledikleri Liderlik Rollerine İlişkin Bir Değerlendirme (Hatay İli Örneği). İnönü Üniversitesi, 2009.

Crabtree, Benjamin F., and William L. Miller. Doing Qualitative Research. Sage, 1999.

Creswell, John W. Educational Research: Planning, Conducting, and Evaluating Quantitative and Qualitative Research. Pearson, 2002.

Dönmez, Özlem. Türk Eğitim Sisteminde Kullanılan Yönetici Metaforlarl (Kayseri Ili Örneği). Erciyes Üniversitesi, 2008.

Erçetin, Sule. Lider Sarmalında Vizyon. Öder Matbaacilık, 1998.

Fraenkel, Jack R., et al. How to Design and Evaluate Research in Education. McGraw-Hill, 2011.

Gök, Ramazan. "The Perceptions of School Administrators Concerning "Merit" Concept: A Metaphor Study.” Journal of Pedagogical Research, vol. 4, no. 3, 2020, pp. 299-311.

Günbay1, İlhan. "Principals' Perceptions on School Management: A Case Study with Metaphorical Analysis." International Online Journal of Educational Sciences, vol. 3, no. 2, 2011, pp. 541-561.

Hargreaves, Andy, and Alma Harris. Performance Beyond Expectations. National College for School Leadership, 2011.

Hargreaves, Andy, et al. Uplifting Leadership: How Organizations, Teams, and Communities Raise Performance. Wiley, 2014.

Harris, Alma. "Uplifting Leadership: Leading Futures." Australian Educational Leader, vol. 37, no. 1, 2015, pp. 19-20.

Hay, Iain. Qualitative Research Methods in Human Geography. Oxford University Press, 2000.

Hoy, Wayne K., and Cecil G. Miskel. Eğitim Yönetimi Teori Araştırma ve Uygulama. Nobel Dağıtım, 2010.

Knowles, Murray, and Rosamund Moon. Introducing Metaphor. Routledge, 2006. 
Korkmaz, Mehmet, and Mehmet Sabir Çevik. "Secondary School Teachers' Metaphorical Perceptions of the Concept of Principal." Journal of Theoretical Educational Science, vol. 11, no. 4, 2018, pp. 973-1002.

Lakoff, George, and Mark Johnson. Metaphors We Live By. University of Chicago Press, 2003.

Marshall, Catherine, and Gretchen B Rossman. Designing Qualitative Research. Sage, 2014.

Memişoğlu, Salih Paşa, and Ömer Yılmaz. "Methaphoric Perceptions of Academic Staff of Faculty of Education on the Concepts of Leader and Leadership." The Journal of Academic Social Science Studies, no. 75, 2019.

Miles, Matthew B., and A. Michael Huberman. Qualitative Data Analysis: An Expanded Sourcebook. Sage Publications, 1994.

Moustakas, Clark. Phenomenological Research Methods. Sage Publications, 1994.

Saban, Ahmet, et al. "Öğretmen Adaylarının Öğretmen Kavramına Ilişkin Algılarının Metafor Analizi Yoluyla Incelenmesi." Kuram ve Uygulamada Eğitim Bilimleri, vol. 6, no. 2, 2006, pp. 509-522.

Sabuncuoğlu, Ebru Tolay. "Liderlik, Değişim ve Yenilik." Liderlik ve Motivasyon. Edited by Celalettin Serinkan, Nobel Yayınları, 2008.

Şahin, Ahmet, and Ali Sabanc1. "Perceptions of Prospective Teachers Attending Pedagogical Formation Courses Regarding the School Administrators and Teachers: A Metaphorical Study.” Turkish Studies, vol. 13, no. 4, 2018.

Schechter, Chen. "Switching Cognitive Gears: Problem-based Learning and Success-based Learning as an Instructional Frameworks in Leadership Education." Journal of Educational Administration, vol. 49, no. 2, 2011, pp. 143-165.
Seidman, Irving. Interviewing as Qualitative Research: A Guide for Researchers in Education and the Social Sciences. Teachers College Press, 2006.

Semerci, Çetin. "A View to the New Primary School Curricula with the Metaphors Relating to Curriculum Development." Cumhuriyet Üniversitesi Sosyal Bilimler Dergisi, vol. 31, no. 1, 2007, pp. 139-154.

Şişman, Mehmet. Öğretim Liderliği. Pegem A Yayıncilık, 2002.

Spillane, James P., and Enrique C. Orlina. "Investigating Leadership Practice: Exploring the Entailments of Taking a Distributed Perspective." Leadership and Policy in Schools, vol. 4, no. 3, 2005, pp. 157-176.

Van Kupperberg, Daan, and Sim B. Sitkin. “A Critical Assessment of Charismatic-Transformational Leadership Research: Back to the Drawing Board?" Academy of Management Annals, vol. 7, no. 1, 2013.

Witherspoon, Noelle, and Emily R. Crawford. "Metaphors of Leadership and Spatialized Practice." International Journal of Leadership in Education, vol. 17, no. 3, 2014.

Yalçın, M. Illköğretim Okullarında Okul Müdürlerine Ilişkin Metaforik Algllar (Yayımlanmamış Yüksek Lisans Tezi). Gaziosmanpaşa Üniversitesi, 2011.

Yalçın, Mikail, and Aysun Erginer. "Metaphoric Perception of Principals in Primary Schools." Journal of Teacher Education and Educators, vol. 1, no. 2, 2012, pp. 229-256.

Yıldırım, Ali, and Hasan Şimşek. Sosyal Bilimlerde Nitel Araştırma Yöntemleri. Seçkin Yayınevi, 2011.

Yıldız, Kaya, and Ramazan Ertürk. "Teachers' Views on the Administrator and Leadership Concept: A Metaphor Study." Bolu Abant İzet Baysal Üniversitesi Ĕ̈itim Fakültesi Dergisi, vol. 19, no. 4, 2019, pp. 1190-1216.

\section{Author Details}

Serdar Özçetin, Assistant Professor, Akdeniz University, Antalya, Turkey, Email ID: serdarozcetin@akdeniz.edu.tr 